\title{
ADGRL3 wt Allele
}

National Cancer Institute

\section{Source}

National Cancer Institute. ADGRL3 wt Allele. NCI Thesaurus. Code C150274.

Human ADGRL3 wild-type allele is located in the vicinity of 4 q13.1 and is approximately $877 \mathrm{~kb}$ in length. This allele, which encodes adhesion G protein-coupled receptor L3 protein, is involved in neuronal migration, cell-cell adhesion and G protein-coupled receptor signaling. 